\title{
Survival Behaviors Of 100-Year-Old West Michigan Retail And Service Companies
}

Vicki TenHaken, (E-mail: tenhaken@hope.edu), Hope College Elizabeth Cohen, (E-mail: elizabeth.cohen@hope.edu), Hope College

\begin{abstract}
This study of small and medium size retail and service companies over 100 years old looks for common strategies that enabled the organizations to prosper for an unusually long period of time. Four common behaviors are identified and compared to factors identified in previous studies of very large multinational companies of a similar age.
\end{abstract}

\section{INTRODUCTION}

fundamental objective of the firm, though often unstated, is survival. As Arie de Gues explains in the
prologue to his book The Living Company:

Like all organisms, the living company exists primarily for its own survival and improvement to fulfill its potential and to become as great as it can be... You exist to survive and thrive; working at your job is a means to that end. Returning investment to shareholders and serving customers are a means to a similar end for IBM, Royal Dutch/Shell, Exxon, Procter \& Gamble, General Motors, and every other company. ${ }^{l}$

Companies focus on profitability, but the underlying reason for making a profit is to continue to "live," or stay in business. However, most firms do not "live" as long as they could. The Shell study described in The Living Company calculated the average life expectancy of a large multinational corporation at 40 to 50 years. $^{2}$ These are companies that have already survived their first 10 years, a period of high corporate mortality. In some countries, 40 percent of all newly created companies last less than 10 years. ${ }^{3}$ A 1996 study by Stratix Consulting Group calculated the average life expectancy of firms in Japan and much of Europe, regardless of size, at 12.5 years. A 2004 study by Hewitt Associates indicated the average life span of companies today is 12-15 years.

By identifying, monitoring and acting on the right factors, the average human life span has increased over $80 \%$ in just one century. ${ }^{4}$ Humans have learned what behaviors increase longevity: a balanced diet, regular exercise, monitoring blood pressure and cholesterol, etc. If the life expectancy of a person can increase through the identification of longevity factors, why can't a company's?

de Gues suggests that the natural average life span of a corporation could be as long as 200-300 years. ${ }^{5}$ When evaluating company performance in terms of years of existence vs. potential, most firms are dismal failures - even if the natural corporate life span is lower than de Gues' estimate. One reason for these premature deaths may be that unlike humans - corporations have not identified and cultivated the factors needed to increase longevity. As a result, many companies do not "live" as long as they could.

Why be concerned about corporate longevity? As de Gues says in The Living Company, the damage that results from the early demise of otherwise successful companies is not merely a matter of shifts in the FORTUNE 500 list: "Work lives, communities, and economies are all affected, even devastated, by premature corporate deaths." 6 It is not just the owners or investors in a company that profit from an organization's survival, but employees, customers, suppliers, and communities all benefit as well. The purpose of this study is to identify corporate behaviors for survival 
that new companies hoping to survive long into the future can incorporate into their strategies.

\section{METHODOLOGY}

This study surveyed firms over 100 years old to see if they share common characteristics that have enabled their long lives. By focusing on a defined geographic area of west Michigan, a fairly complete data base of companies over 100 years old could be identified. One hundred years was chosen as a defining point because by then the companies had survived changes in ownership, several generations if a family-owned company, as well as the many significant economic and environmental challenges of depression, world war, advances in technology, etc. The focus of this study is surviving control firms. Companies were not included if they were bought out by other organizations, even if a local facility continued to operate as a branch business or subsidiary: if the new ownership was located elsewhere, the company was considered too changed to qualify for this study. Though publicly-owned companies were not excluded from the data base, all companies in this study are privately-owned. (In fact, most companies described "Remaining a private company" as an important factor in their firm's long-term survival.) Also not included in the data base were not-for-profit organizations or family farms. Difficulties in compiling an exhaustive data base led to a focus in this study on retail and service firms. The Michigan Retailers Association was the only organization contacted that kept a data base of century-old organizations. ${ }^{7}$ Of the total data base, common survey information was obtained from 37 percent of the companies and in-depth interviews were conducted with 25 percent.

\section{COMPANY PROFILES}

Thirty-eight percent of the companies studied were service organizations (such as funeral homes); the others were retailers. However, not all companies were entirely consumer focused businesses - some of the retailers also had commercial divisions and some of the service companies were purely "business-to-business" entities.

Fifty percent of the companies in this study are 100-125 years old, and half are over 125 years old. The oldest companies included in the study were established in 1860. (One company was founded in 1882 by an immigrant whose family had been in the same business in the Netherlands for 400 years.) Half of companies studied were also very small, with sales of less than $\$ 2$ million per year. Ten percent are over $\$ 2$ million but less than $\$ 10$ million; another ten percent are in the $\$ 10$ to $\$ 50$ million range. Twenty percent reported annual sales of $\$ 50$ to $\$ 150$ million, and another ten percent over $\$ 150$ million, with the largest at $\$ 300$ million.

As mentioned previously, all of the companies in this study are privately held. Half of the firms are still owned by members of the founding family - one in the seventh generation. Of the half that are not still owned by members of the founding family, three-fourths are already into multiple generations of the current family ownership two in the fourth generation and one in the fifth.

Table 1: Profile of Companies Studied

\begin{tabular}{|c|c|}
\hline Mean Age & 126 years \\
\hline Average Number of Employees & 142 \\
\hline Average Annual Sales & $\$ 46.9$ million \\
\hline Privately Held & $100 \%$ \\
\hline Average Generations of Family Ownership & 4 \\
\hline
\end{tabular}

\section{RESULTS: HOW DID THESE COMPANIES SURVIVE?}

How have these companies been able to overcome many environmental changes and economic challenges to thrive over one hundred years? Are there any common strategies or behaviors employed by these companies that may have led to their long lives? Following are the results of this study. 


\section{Focus Strategy}

All companies surveyed indicated that a focus strategy was an important factor in their firm's long-term survival. Three-quarters of the companies surveyed said that having a particular business focus or niche in which they have built a reputation was "extremely important" (\#1 on the Likert 1-5 value scale); the other 25 percent said such a focus strategy was "important." And 62 percent of the companies reported that keeping focused on their main business was "extremely important," with the other 38 percent saying it was "important."

One common practice that is a result of this strategy is that nearly 90 percent of the companies have retained the same company name under which the business was founded, even when it was a family name and a new family purchased the company. Once a reputation was built, the companies were reluctant to change the name under which the company did business, even if it was named after a founder whose family was no longer involved in the company.

Though some companies surveyed indicated they had sought new business opportunities over the years, growth was not a driving force. In fact, 40 percent of the companies said they have not actively sought to grow their business; and of the 60 percent who did, none of them said it was "extremely important" in their firm's success. For most firms, keeping focused on the business where their reputation had been built was more important than growth particularly if growth meant branching out into new areas.

\section{Employees Truly Are Their Most Important Asset}

Almost all (88 percent) of the companies surveyed indicated that having loyal, long-term employees was a critical factor in their firm's success and long-term survival. Similar to the previous factor, two-thirds of the companies said that having loyal, long-term employees was "extremely important."

A common practice reported by these companies was keeping employees on the payroll even when they didn't have enough work to keep them productively employed. Significantly, all companies surveyed said they had done this and all of them indicated it was either an "extremely important" (50 percent) or "important" factor (50 percent) in their company's long-term success.

Another practice many companies said they employed in carrying out this strategy was to pay above average compensation. Some said that, since they were a small business, there was no way they could afford to pay employees "what they were really worth" but they offered other benefits, such as flexible work hours, to make their company an attractive place to work and to retain employees. Interestingly, 88 percent of the companies surveyed said they have some form of profit-sharing or bonus plan in place for employees. Half felt this was an "extremely important" factor in the firm's long-term survival and 38 percent said it was "important."

\section{Service, Service, Service}

The only other strategy that scored consistently high among all companies surveyed was customer service. Eighty-eight percent said that maintaining close relationships with their traditional customers was an "extremely important" factor in their firm's long-term survival and the other twelve percent said it was "important."

This strategy may seem obvious, since this study focused on retail and service firms - which by their very nature must be customer-focused to survive, even in the short-term. However, it was interesting that only one-third of the companies indicated that investing in developing new customers was "extremely important" (and some were quite neutral - or even negative - on the whole idea of advertising or market development).

Perhaps the practice that is most indicative of this strategy is that all of the companies said that they had continued to offer products or services that their traditional customers valued, even if they didn't make any money - or even lost money - doing so. They saw this as an important factor in retaining customer loyalty. Similar to keeping employees on the payroll, even when they didn't have work to keep them busy, these companies would do whatever they needed to keep their loyal customers, even if it did not appear to be a financially sound decision for the business. 


\section{Driven By Core Values}

Though 88 percent of the companies indicated they had strong company values or beliefs, few had written statements of these core values and some had difficulty expressing them succinctly (and a few weren't even sure what the interviewers were talking about). However, most had strong oral traditions that they represented in sayings such as "When the store is open there's always a (family name) on the floor" or "The customer is always \#1 - that means you call them by their name" or "Treat a kid with 10 cents to spend the same as you would an adult with $\$ 10$." Some were simply common sayings such as "We follow the Golden Rule: Do unto others as you would have them do unto you" or "Be fair and honest" or "We don't play pricing games - we offer a good, first deal."

There were no common practices identified that supported this strategy. The company values were not written documents and the companies did not indicate there was a deliberate effort to teach them to new employees. These "values" seemed to be more a way of doing business that was instilled in employees through the owners' behaviors; since most of the companies had employees that were also with the company for a long time, their behaviors embodied these values as well.

\section{COMPARISON TO LARGE COMPANY SURVIVAL STRATEGIES}

How do the survival characteristics of small to medium size, private, West-Michigan retail and service firms compare to the factors identified in studies of very large old firms? A little over one-third (38 percent) of the large companies profiled in the Collins and Porras book Built to Last were over 100 years old when the research was conducted. However, the criterion used was only that the company was founded before 1950, so many of the Built to Last companies have not survived as long as the companies in this study (and in fact two of the companies were founded as recently as 1945 and have not gone through multiple generations of leadership). Shell's study described in The Living Company provides more comparable information, since their research was conducted on large companies that were well over 100 years old. The four common factors of the long-lived large companies identified by de Geus in The Living Company are: ${ }^{8}$

1. Sensitivity to the environment - a company's ability to learn and adapt

2. Cohesion and identity - a company's ability to build a community and a "persona" for itself

3. Tolerance for experimentation and decentralization - symptoms of a company's ability to build constructive relationships with other entities within and outside itself

4. Conservative financing - a company's ability to govern its own growth and evolution effectively

At first blush, it seems clear that the behaviors large companies must engage in to succeed and survive long term are quite different from those of the small service and retail firms studied. Perhaps these differences are because most of the large global firms studied by Shell are manufacturing or industrial firms. However, upon closer examination, there are some similarities.

The smaller retail and service firms in this study did seem less likely to invest in new product or business development or in modernizing their management systems and processes than did the large companies in Shell's study. And the companies in this study did not even appear to be particularly concerned about new, large competitors entering their market. However, they did learn and adapt over time, or they would not have survived over 100 years. The difference is that the companies in this study did so by listening to their traditional customers and responding to their needs rather than by engaging in deliberate "learning strategies" or environmental scanning practices that would keep them aware of new developments in their external environment.

Though the companies in this study would not use the terms "cohesion and identity," many of their stories talked about building relationships with customers and the local community. The importance they placed on their brand name and reputation, which builds the image of the company both with employees and in the marketplace, is very similar to how de Geus describes his second factor and the relationships that he says are critical to making the third factor work. Since most of the companies in this study are quite small, the issue of decentralization was not a factor. 
Although there was no consensus among the companies in this study that this is a critical factor in their longterm survival, most of the firms did describe themselves as being conservative in their financing, as in the Shell research. This is likely as much a factor of their size as it is of any deliberate strategy.

\section{CONCLUSIONS AND RECOMMENDATIONS}

Based solely on the availability of a data base, one could speculate that it is more likely that firms engaged in retail sales or other direct service to customers are more likely than general manufacturing companies to live long lives. Or perhaps the economies of scale often required for survival of manufacturing firms entices these companies to engage in growth behaviors that may appear necessary for success in the short run, but do not enable long-term survival. Though the data base of manufacturing companies that are over 100 years old will be smaller, it is our intent to study these organizations in the next phase of our work. It is our belief that a company desiring a long, profitable life may benefit by learning about the behaviors of the long-lived firms in this study: If the life expectancy of a person can increase through the identification of longevity factors, why can't a company's?

\section{REFERENCES}

1. $\quad$ Business Basics: People \& Performance. 2004. Hewitt Quarterly Asia Pacific.

2. Collins, J., Porras, J. 1994. Built to Last: Successful Habits of Visionary Companies. HarperCollins Publishers, Inc: New York, NY.

3. de Geus, A. 1997. The Living Company. Harvard Business School Press: Boston MA.

4. de Rooij, E., 1996. A brief desk research study into the average life expectancy of companies in a number of countries. Stratix Consulting Group: Amsterdam

5. Iwasaki, N, Kanda, M. 1996. Sustainability of the Japanese Old Established Companies. Economic Institute of Seijo University 132: 160-130.

6. Royal Dutch/Shell Group Planning PL/I. 1983. Corporate Change: A Look at How Long-Established Companies Change

\section{Footnotes}

${ }^{1}$ deGues, A. 1977. The Living Company. Harvard Business School Press: Boston, MA. 11

${ }^{2}$ Royal Dutch/Shell Group Planning PL/I. 1983. Corporate Change: A Look at How Long-Established Companies Change

${ }^{3}$ The Living Company, 2

${ }^{4}$ The average human life span has risen from a life expectancy of 40 in the early 1900s to 75 years at the turn of the century. 2004, Hewitt Quarterly Asia Pacific, 3.

${ }^{5}$ The Living Company, 2

${ }^{6}$ The Living Company, 3

${ }^{7}$ The Michigan Manufacturers Association, The Michigan Historical Society, and various Chambers of Commerce were all contacted and do not keep such a data base.

${ }^{8}$ The Living Company, 9 


\section{NOTES}

